\title{
Co-opted Marginality and Social Media in Singapore
}

\author{
Claire Stravato Emes \\ Nanyang Technological University \\ Claire001@e.ntu.edu.sg
}

\author{
Arul Chib \\ Nanyang Technological University \\ ArulChib@,ntu.edu.sg
}

\begin{abstract}
Social media provide a platform for groups that are not conventionally ostracized to claim marginality. This study proposes a working definition for the phenomenon of "co-opted marginality" within the context of communication on social media. The phenomenon is examined in the Singaporean context; 17 Singaporean citizens were interviewed about their experiences with immigration online and offline. We find that, within constrained legal, social, and traditional media environments, social media provides a platform for a dominant group facing challenges to enact co- opted marginality.
\end{abstract}

\section{Introduction}

Media reports worldwide provide occurrences of groups or individuals who claim marginality while their actual position would not appear to substantiate such claims. Some notable moments of co-opted marginality include the trading tagline, "it's okay to be white." This tagline first appeared on 4chan and made a noticeable public appearance the day US White supremacist personality Lauren Southern touched down in Australia wearing a t-shirt displaying the controversial meme [1]. The example elicits the notion that despite their relative positions of high status, individuals perceive themselves as being social underdogs and marginalized.

This study examines theoretical avenues and empirical evidence of co-opted marginality in the Singaporean context, where numerous claims of coopted marginality have been emerging on social media.

Singapore, a poster child of globalization, is hailed as a model state for fostering a strong sense of belonging among multicultural citizens of ethnically diverse backgrounds [2]. The city-state has, throughout the years, maintained a reliance on the import of both low- and high-skilled foreign workforce, aimed at achieving twin goals of economic development and social welfare [3]. Acknowledged as one of the wealthiest nations on earth, Singapore has pursued a distinctive development model that prioritizes the creation of shared economic opportunities for all its citizens [4]. The government has invested heavily in citizens' capabilities to participate effectively in a productiveeconomy by promoting education and offering economic entitlements (public housing and social security system via a mandatory savings scheme).

However, Singaporeans have recently denounced their lack of equal opportunities vis-à-vis foreigners [5]. In May 2014, 12 independent groups, including Maruah, Singapore's leading human rights group, reported a worrying trend to "blame foreigners for social ills" such as overcrowding or local unemployment. These manifest through anonymous posts online that mostly emphasize the frustrations of feeling marginalized by "inequitable policies" [6]. Citizens protest that they are being discriminated against and replaced by foreigners, calling themselves "second class citizens" [2].

\subsection{A country of immigrants}

Since its heyday as a trading post in the $19^{\text {th }}$ century, Singapore has sustained an open-door policy for immigrants. More recently, over the past two decades, the city state has conducted one of the world's greatest experiment in mass immigration. From 1999 to 2018, Singapore's total population grew over $40 \%$ to some 5.6 million, largely through immigration, in comparison with global cities such as London and New York, which grew at 25\% and 13\%, respectively [7].

The authorities portray the influx of migrant labor as an economic imperative [8]. In 2012, Prime Minister Lee Kwan Yew declared "Like it or not, unless we have more babies, we need to accept immigrants" [9]. Other motivations are attributed to the aspirations of the country's "technocratic" leadership within a narrative that pits Singapore as a bridge between the East and the West [10]. The "gateway" frame relies on attracting talented individuals to promote the city's economic growth. The recruitment policies for the brightest, most ambitious, commonly named "Foreign Talents", has 
successfully contributed to the flourishing economy of the city state whose GDP per capita is one of the highest in the world, ahead of the USA and Japan [11]. However, the policy has impacted the social fabric of the nation.

The perceived rise and prominence of "Foreign Talents" within the Singapore economy have triggered anxieties and soul searching among bornand-bred Singaporeans who converge on social media to vent their anger. The Facebook groups "SGOpposition" (52k followers) or "Concerned Citizens Band Together for a better Singapore" abound in posts of personal stories lamenting how foreigners have it all. A young disenchanted Singaporean captured widespread attention (over 1000 likes) by recounting her experience at work: "I just got a notification that a foreigner in my company is the new GM of my department.. only HR has a local manager. In my own team, I am the only Singaporean... It's not about working harder, longer, or cheaper. It's about not having protection from the very own government who is supposed to protect our livelihoods...They claim that it is those tech-specific jobs that Singaporeans cannot do. Really? You mean that all the young students in polytechnics and universities cannot be trained to have tech skills for a digital Singapore? Then what the hell are schools for? To create subordinates for our foreign managers?" [12].

Talks about the government's need to protect 'Singaporeans First' amid the arrival of a growing number of economic migrants is not new and have been circulated online since the emblematic 'cook and share a pot of curry' campaign in 2013 [13]. The campaign was a response to a mediation agreement imposed upon a Singaporean household to restrain from cooking curry - the smell of which inconvenienced their Chinese migrant neighbors. The case was met with outrage by Singaporeans who felt that cooking curry was a marker of national identity, and 57,000 supporters gathered on Facebook to encourage people to cook curry [14]. Ever since then, community news sites on social media (Mothership, Stomp, etc.) continue to feature occurrences of rows involving typically self-entitled and well-off foreigners that disrespect locals or local rules [15].

The government has reacted to the brewing discontentment with the distribution of 'perks' to citizens along with withdrawals of subsidies and increases of taxes on noncitizens; measures were also taken to dissuade the employment of foreigners by regularly toughening up rules around workforce as well as access to work visas [16]. 2016 marked the first year in decades where the annual change in foreigners at work in Singapore was reported as negative by the Ministry of Manpower [17]. The Republic of Singapore's President Halimah Yacob acknowledged concerns about foreigners affecting Singaporean's sense of identity and belonging, declaring "as masters of our own land, Singaporeans must have confidence in the rights and privileges of citizenship" [18].

The objective of the paper is to identify the negative rhetoric of Singaporeans towards foreigners as belonging to the vocabulary of co-opted marginality and understand, given Singapore's unique context, the role of social media as an enabler for such discourse.

We first propose and justify theoretically the choice of the term marginality in the identification of "co-opted marginality".

\section{Theoretical roots of co-opted marginality}

Marginality is traditionally conceptualized within a framework of uneven distribution of power in society. Complex factors causing poverty (resource endowments, political systems, environmental drivers) are associated with marginality. The standard definition infers that social, political, economic, or ecological systems affect and push individuals to the margins of society, wherein they suffer restricted access to resources, limited freedoms, and poverty [19] However, most of all, marginalized groups are excluded from fully engaging in the process of communication and face structural impossibilities in harnessing the power of media [20].

The concept of marginality has been critiqued as elusive and lacking construct validity. Definitions of marginality have been subject to debate and misinterpretation [21], [22]. Park [23] first used the term to describe the predicament of ambiguous belonging, which characterizes the situation of transitions such as migration or class changes. Marginality simultaneously points to the mental disorganization of a person fated to live at the intersection of two worlds (cultural marginality) and to the alienation arising out of the social position of an aggrieved individual or group (structural marginality) [24]. While conceptualizations of marginality in the literature vary, these essentially converge towards an analytical regime of categorization to identify where the center and the periphery of power hierarchies lie.

\subsection{Marginality as a relative concept}

As advocates of a pragmatic critique of society, Boltanski and Thévenot maintain that actors' sense of reality is sustained by a grasp of their social 
environment [25]. People compare their situation with that of others whose professional or personal success has been greater than theirs, and their sense of justice is shaped and justified by this comparative capacity. This is also heavily influenced by various instruments developed by the leaders (managers, politicians, etc.). In this manner, understanding people's sense of justice and how they position themselves in the social hierarchy requires one to adopt a metacritical position that considers people's experience through the prisms of their social context and the information they receive and consume.

Goffman argues that the sense of a collective emerges via rituals of interaction; rituals, in this instance, are mechanisms that develop a sense of solidarity among individuals by generating common meanings and common knowledge [26]. The meshing of interaction ritual chains constitutes a sort of social structure composed of groups whose memberships depend on the symbols that have been created during encounters [27], [28]. Society is thus composed of a bounded "social world" whereby an individual unable to take part in the discursive action of a group or a social world cannot develop the necessary solidarity and is left at the margins.

A pragmatic critique of domination and interaction rituals suggests that perceptions of marginality do not necessarily answer the functional and structured nature of social hierarchy. It may be the result of complex situated and relational subjectivities that are fashioned by the interactional rituals people engage in, or the social world in which they partake. It may also flow from their sense of justice and justification. In this manner, marginality can be the outcome of how one perceives his or her identity and position relative to others, and it can be applied to individuals or groups that are not traditionally considered as evolving at the margin. These considerations substantiate a link between the concept of marginality and the claims of dominant groups that we previously documented.

We posit a working definition of the phenomenon of "co-opted marginality" as an identity claim articulated by a dominant group that is based on the shared but paradoxical interpretation of being marginalized. For conceptual clarity, co- opted marginality is not defined as a fantasy but rather as a discourse of marginalization shared among members of a dominant group that constitutes the basis of a collective identity constructed via social media. Coopted marginality deviates from marginality in the sense that it does not originate from social power structures, but it is incited by rituals of interactions and by narratives that specifically antagonize others (i.e., immigrants, feminists, Muslims, foreigners, elites, etc.).

\subsection{Co-opted marginality, ignored and condemned}

Neuman [29] argues that communication research is generally sympathetic towards minorities and groups evolving on the margin of power. A review of marginality in the context of the communication literature suggests that the term has mostly been used to characterize individuals placed on the receiving end of prejudices or those that are excluded from taking part in communication processes. The extent to which institutions built around communication consolidate and maintain political, economic, and cultural elites, as well as exclude marginalized groups, is a longstanding concern in the literature [30].

In traditional mass communication models, people living at the periphery of the system are susceptible to or dependent on the voice of sympathetic cultural elites (journalists, film directors, authors, politicians, etc.) to access the public sphere [29]. Co-opted marginality reverses this sympathetic tendency, as speaking of privilege is not well accepted by the cultural elite. Co-opted marginality claimants are ostracised as maladjusted or as individuals driven by bigotry and xenophobia. Indeed, discrimination against foreigners in Singapore is explicitly condemned. The serving Minister for Trade and Industry, Chan Chun Sing, while asked to publish a breakdown of employment data between foreigners and local Singaporeans during the parliament session in January 2020, dismissed the concern by claiming, "The insinuations seem to be that somehow the Singaporeans are not benefiting...The ultimate competition is not pitting the Singaporeans against the PR [permanent resident], it is about the team Singapore comprising Singaporeans, the $P R$ and even the foreign workforce ... competing to give Singaporeans the best chance possible" [31]. Similarly, commentators in the mainstream press point to the presence of demeaning tweets and posts about foreigners as "the perennial issue of xenophobia in Singapore" and as a sign of passive, reprehensible, and even dangerous attitudes of citizens towards foreigners [32].

\subsection{Emerging influences on social media}

Singapore's relationship with political pluralism is complex, given the state's cultural and multi- ethnic background. The People Action Party (PAP), Singaporean's incumbent ruling party, in power since the small state's independence, is credited for Singapore's survival after the days of expulsion from Malaysia in 1965, which is viewed as nothing more 
than a wonder. To this day, the PAP's dominant rhetoric of survival taps into the collective fears of ordinary Singaporeans who have internalized the need to contribute. This has led to a strong sense of collective pride but also emphasized a materialistic outlook that manifests into political apathy as remunerative goals precede political ones [33]. The PAP has developed a powerful influence on the evolution of Singapore's professional journalism with the view to protect the nation- building project [34]. As articulated by Prime Minister Lee Kuan Yew (1971), "In such a situation, freedom of the press, freedom of the news media, must be subordinated to the overriding needs of the integrity of Singapore, and the primacy of purpose of an elected government" [34].

Opportunities for opposition and mobilization in the public sphere for antagonistic voices, however, emerged with the Internet [35]. Citizens have been exploring institutional paths for political influence and have shaken a 'managerial state' that until then had little fear of electoral backlash [36]. Social media "has amplified divergent opinions and bypassed a tightly controlled media that over the years has acted less like a watchdog and more like a cheerleading squad for the government and its ambitions" [37]. Since 2010, communities and news web sites emerged, adopting at times a critical stance towards government policies.

The State Times Review (STR), whose editor Alex Tan is based in Australia, and the Online Citizen (TOC) led this effort. The TOC was gazetted as a political organization, but under the Political Donations Act, the organization's access to resources remained restricted, unable to receive funds from foreign contributors In February 2019, The STR was blocked after publishing an article on the 1MDB state fund scandal; TOC was investigated for criminal defamation over the publication of the same story, and de-gazetted. The turn of events prompted the Ministry of Law to emphasize the need to introduce legislation to stop fake news. Since April 2019, the Online Falsehoods and Manipulation Bill, presented as the first-ever effort garnered by a national government to regulate social media, has invoke legal restrictions to serve the public interest and protect society from damage by online falsehoods created by "malicious actors" [38]. A few writers and academics based in Singapore and abroad have expressed concerns that people may be deterred from commenting online [38].

Still, the importance of social media in the Singaporean political landscape has endured and strengthened. The General Election in 2020, \#GE2020, was dubbed by the local daily Straits Times as a social media election [39]. Campaigning with the context of COVID19 social distancing measures meant candidates could mainly rally participants on social media.

Given the nascent and influential role played by social media in the Singaporean public sphere, it is fitting to explore why and how the platform may contribute and facilitate the spread of co-opted marginality in Singapore.

\section{Method}

The author, a female of Caucasian origin and a Singaporean PR, interviewed 17 citizens (11 males, 6 females). Participants were recruited on social media from Reddit, Facebook community sites and Hardware Zone (a community site hosted by Singapore Press Holdings and famous for countercultural activities, where mostly male users use a distinctive vocabulary mixing the local dialect Singlish with memes). Potential interviewees were identified from studying a pool of comments that discussed immigration issues. Participants were mainly Chinese Singaporean citizens, except for one identified as Malay and four as Others according to the CMIO (Chinese, Malay, Indian and Others) classification. The interviews were conducted in English and lasted from 45 minutes to 1.5 hours. Participants were informed that they would be asked about their perception of immigration issues in Singapore and of the discourse about immigration on social media. They are referred to with pseudonyms in this article.

The fact a non-Singaporean led interviews requires caution in the analysis of the data. According to Ganga and Scott, being insiders in the social interview paradoxically makes awareness of different worldviews and social divisions even more acute [40]. In this study, the researcher's position of an outsider may offer a nonpartisan channel for voicing authentic and subjective views. Similarly, her position as a foreigner may have dampened negative rhetoric about foreigners among interviewees; while this position is moderated by her status as permanent resident.

While the findings outlined below are not meant to be representative of all social media users in Singapore online public sphere, we aimed to capture individuals' identity constructions as co-opted marginality claimants and gauge the role of social media in making the identity salient. The qualitative interviews allowed for critically exploring how interviewees defined their social position vis-à-vis foreigners and how their personal experience versus the information they receive and consume on social media influence their perceived positionality. This method allows for assessing interviewees' subjective understandings of their everyday experiences of differentiation with foreigners - including the 
confrontations and the underlying prejudices - as well as the influence of exposure or even active participation on social media. We next present the three key domains influenced by social media (cultural and racialized social legacy; depreciated public sphere; collective validation processes), which affect how Singaporean citizens demarcate and establish new collective identities.

\section{Findings}

\subsection{Social media and the cultural legacy: Racial harmony to co-opted marginality.}

Singapore is referred to as a successful model of a multicultural nation [41]. Singapore was built on promises for a better future, housing since the $19^{\text {th }}$ century a diverse ethnic population hoping for a better life. Singapore is the only nation outside Greater China with a majority Chinese population, descendants of earlier immigrants [42], and home to significant Malay and Indian minorities. The diversity of the ethnic population has been both an asset and a challenge for development and has carefully been administered by strict multiculturalist policies. Singapore's objective for a cohesive and harmonious society relies on the embeddedness of cultural identity in a non-threatening social climate [41], which is supported by laws that restrict any expression that would disrupt racial and religious harmony (Section 298 of the Penal Code). It is a liable offense to speak words within hearing distance of a person that have deliberate intention to wound that person's religious or racial feelings.

Journalists and scholars claim social media has brought budding dissent among a younger generation who feel slightly more inclined to talk openly about the concept of racial tolerance online, a conversation that is still uncomfortable to most Singaporeans [43]. Graphic and explicit racial tensions and fights regularly emerge on social media. Yet, respondents emphasize the powerful hold that racial harmony laws still have. Brenda, a

28 year-old administrative assistant, confirmed "There is a lot of tension between Malays and Chinese, between Indians; but we don't talk about it. No one does".

In contrast, social dissatisfaction about nonSingaporeans are openly and freely discussed. As Kyle explained "You do not find people talking about race, It's more about foreigners." The viewpoint was vindicated when MP Raeesah Khan, a young Malay member of the opposition Workers' Party and recent parliamentary elect, posted a tweet invoking racial injustice about an incident involving foreigners who were caught on camera while ignoring safe distancing rules during the circuit breaker period: "Do you see police officers here? Imagine if this was a neighbourhood hawker centre. There would be policemen swarming the area and enforcing the law within minutes.... Why is the law different for these people? Is it because they're rich Chinese or white people? Do you think expats will be treated with the same disdain as migrant workers who broke the law?'[44]. The MP made a full public apology after receiving stern warning from the police force, she nonetheless received extensive backing on social media, she was the first political figure to make open critical comments on race, although about foreigners

The idea of foreigners is strongly associated with palpable anxiety over citizens' abilities to succeed in an increasingly competitive economy. Ching summarised the pressure Singapore is under by highlighting his disapproval of Singapore's materialistic and neo liberal pursuits as "just an economic workshop. There is nothing beyond that, to $m e$. There is no significance. I'm not very happy regarding how the country is progressing". The imperative for a flourishing economy has led to the inflow of Foreign Talents (i.e., skilled foreigners) and reinforced the common perception that Singaporeans are not given the right opportunities to contribute to their homeland. Faced with increased skilled competition, Damian, an undergraduate student, lamented that, "Singaporeans are not good enough. That is what I think". Citing the example of an Indian national, Mr. Piyush Gupta, appointed as chairman of Singaporean national bank DBS Derek, an entrepreneur, found this appointment fair to ensure the bank's growth. However, he soon reflected that "It's a mixed bag. My general sentiment is that authorities are very quick to give foreign talents the benefit of the doubt and treat them better than ourselves". Citizens often compared themselves unfavorably to foreign talents. TP, a hedge fund manager, confided, "I might as well move overseas, where there are better opportunities... A lot of these foreigners, they have a degree from Harvard... But if I graduate from NUS [a globally-ranked Singaporean university], even if you are the best, you cannot really compete."

There is a sense of a double-squeeze from both ends of the class structure. At the lower end of the economy, Singaporeans systematically turn away from menial or low-skill jobs, expecting migrants to support the building of its world-class infrastructure. TP acknowledged that "Look at maids and construction workers. These are ok, because ..if you need more houses, you need labor. You cannot expect Singaporeans to do this labor-intensive job". At the 
higher end of the employement scale, Singaporeans feel side-lined. Derek claimed that "Singaporeans say we want to practice meritocracy, maybe we even put in the effort to, but unconsciously, we end up privileging others".

Participants discussed how the perceived change in their social standing appeared unjust and threatening. Brenda expressed the sense of the majority being marginalized, stating "This is the only place we can call home. If we're being outcasted, or we're being kicked out, then where can we go? Even though we are accepting of it, but we still feel a little bit threatened. Like I guess, we are slowly becoming the minorities". Such realization is expressed as anger on social media where Singaporeans vent frustrations. Faizal however remarked that the acrimony does not match the personal experience most people may have with foreigners. When prompted to elaborate about negative experiences, participants' answers usually corroborate with Faizal's remark, "For those [foreigners] whom I have had personal contact with, I find them pleasant people. But unfortunately, online, what we see... the bad behaviors, they are recorded and posted online. Personally, I feel that... migrants from China, India, they are generally nice, hardworking and decent people. However, the portrayal of people from that nationality is negative online".

Overall, the negative rhetoric online is not necessarily seen as symptomatic of a Singaporean brush with xenophobia but a reaction to anxieties maintained by attitudes and aspirations that are cultivated among Singaporeans. Brenna, a young makeup artist, highighted the materialistic emphasis of Singaporean society as a cause and dismissed Singaporeans prejudicial leanings in justifying the contentious content that spreads online. She believed that "Singaporeans are bored; when people are together, they do not discuss ideas. You can't discuss topics like global warming... Everything is just superficial, materialistic things. That's how our society has basically been built on. You can't really find people with enough sustenance in them to carry a conversation".

In the end, presence on social media enables us to identify fault lines within the - mostly young interviewees' cultural legacy. They dare to envisage different options and develop critical stances towards long-held social norms such as racial tolerance. They also acknowledge difficulties brought about by global economic competition, which they attribute to Singapore's overbearing turn towards materialistic objectives.

\subsection{An undervalued public sphere:}

\section{Mistrusted mainstream media and vilified social media}

Asian values, multiculturalist constraints, and a sophisticated legal system have subtly but decisively regulated the public sphere in Singapore. Public conversation is restricted by "O.B. markers" (out of bound), whereby individuals tacitly know what is taboo and what should not be discussed publicly, namely race and politics [45]. XI, a government employee, explained: "you have a freedom of expression in Singapore, it's just that, there are certain lines you should not cross." O.B. markers learned at school, and through different socialization processes support a cultivated "co-option and political discipline" among the citizenry [46].

Participants are, however, wary about the news they receive from the national media. For some, such as Derek, traditional media organizations are credible due to their close relationship with the authorities, explaining that, "If you look at our media organizations, Channel News Asia, TODAY, The Straits Times. I think it's wrong first to think that they're siding the government all the time. No, I don't think so. They're doing their best to give a balanced view... They don't try to spin it. And they don't just... report what they hear. They usually match it with what... they compare it with the Ministry to confirm that this is accurate. That, to me, is credibility".

Nonetheless, given the limited alternative viewpoints available, the mainstream media is regarded with suspicion. A number of participants described mainstream media in Singapore as biased, with Ching explaining, "I trust the BBC completely. I would not second guess the news source.... But I'm very sceptical towards Straits Times. Yes, because I feel that it has always been a government mouthpiece, in the sense that I feel that a lot of news that I've heard about that are not being reported or are not being reported transparently... I have never had any confidence in what they do".

Mainstream media seems irrelevant to younger interviewees who grew up in a hyperconnected world. Local news spreads fast online or fails to cover sensitive topics, often leaving mainstream media in the slipstream. According to Faizal, "Generally, the stories on forums...you kind of know that it's real because, on other platforms, people are talking about it as well. But these are usually not reported on mainstream media". To which Jonathan adds, "mainstream media filter news to prevent any misunderstandings... They want to just report what is real and what is true, rather than what is unconfirmed. But they usually end up publishing facts that were already exposed on social media. There are 
actual cases where the journalists took the photo from hardware zone and actually published it in the papers".

Suspicion is however not solely geared towards mainstream media; interactions on social media do not inspire much more trust. Participants viewed negativity online as overwhelming and demeaning. Faizal, a market researcher, shared experiences from his job browsing forums on social media. He explained that "it did affect my mentality, I felt more jaded more quickly. I felt... the burden to read. Because there was so much negativity. It just affects you, personally. From time to time, I step away from the computer and engage with real people". Damian remarked that such an attitude is even discernible on online mainstream media like the Straits Times comment section, remarking, "whenever they post certain articles, then you go under the comments section, they always like to scold each other. ..some of them would actually create fake profiles ah. Just for the sake of scolding or getting into quarrels".

It is noteworthy to juxtapose participants' opinions of social media with the rhetoric of the authorities. Since its inception, the Internet has been depicted as a suspicious medium. Back in 2009, Lee Kwan Yu referred in a televised interview to a "vehicle for subversion" [47]. Social media has only amplified the divergence in opinions between the public and the government.

Preserving the quality of the public sphere and regulating public discourse on social media has remained an important issue in national politics. Singapore does not officially censor the Internet; dissident political websites and foreign media sites are freely accessible. However, restrictions are set in lieu of heavy registration fees for the mandatory licensing of online political sites, which give the Infocomm Media Development Authority the power to demand political sites to remove content that is deemed dangerous to Singapore politics. The 'Online Falsehoods and Manipulation Bill' of 2019 also upholds criminal sanctions for the deliberate dissemination of fake news that involves hefty fines and jail sentences (up to 10 years) [38].

The critics of the deliberative value of social media was matched with the respondent's view of their declining relevance and quality. Brenda's reflection emphasized issues linked to the quality of the public space online, which she felt verged towards juicy gossip and provocative content rather than serious discussion. "Sometimes when you find an interesting thread right, and the things that people say about the people on the video. It's just so outrageous. It's just crazy. Things that people say. I'm all for the drama. I live for it. I basically live for it. Love it".
Sites such as TOC that were initially launched to offer alternative viewpoints on the Singaporean public sphere are also suspected of exploitative unconstructiveness. $\mathrm{Xi}$ acknowledged that he used to read TOC, but he believed the quality has decreased: "It's like a cesspool. I couldn't stand it anymore. So I get out. I get out not because I don't agree with what I'm hearing, you know. It's quality... It's like... ... I'm not sure how to say this in English, in Chinese it's called trying to... dig bones from an egg... It's like trying to make a big issue out of something small".

Generally, respondents maintained scepticism towards social media. Brenda claimed, when she spent time browsing and consuming news on her feeds of local sites such as Crime Library Singapore, Kaypoh Singapore, Motherships, to see "ugly fighting" and toxicity spreading, remarking that, "they have no message no purpose, it is all about trash... I'm not being serious. I may have a lot of emojis, yeah. So... I may not blatantly say out anything... but I didn't trash the government what. Ok. So you can basically express negativity without saying anything, ah that's not really what I mean. ... I'm just being a keyboard warrior here". Breena added. "They just creep up on you eventually, that kind of thing. Yes. So, that's how I feel about social media. They come and create some troubles here and there".

From a meta critical stance, these observations made by citizens asserted and justified the rhetoric held by authorities in Singapore about the risks and perils of social media.

\subsection{Social media as an enabler of collective identity in a divided society?}

Paradoxically, despite strong reservations towards the deliberative value of discussions on social media, participants conceded their influence when validating their personal opinions. Although barely endorsing active roles online, interviewees acknowledged the collective value of the messages they received from social media.

First, interviewees claimed to 'fish' for news on online forums, read articles and posts, and share these with friends but they remained reluctant to engage as producers of content. Echoing the literature on conformity and the fear of speaking out as outlined by Noelle- Neuman's "spiral of silence"

[48] interviewees were hesitant and rarely commented or discussed seriours issues online. Derek explained his attitude towards posting online, "Food reviewers were getting in trouble at restaurants because they gave a bad review. So if something as minor as this, you get into trouble. There's nothing wrong with me sharing a piece of news. You can't 
fault me for sharing a piece of news. But you can fault me if I make a comment that's unfair. You see. So rather not comment".

Beyond the pressure of social norms, online content can lead to regulatory judgments. In 2016, a young pregnant Japanese Australian woman received a 10-month jail sentence for posting on a website called "the real Singapore" articles deemed to incite ethnic hatred [49]. Participants engaged in selfcensorship, too aware that participation in public forums such as Facebook was not anonymous. The fact, however, that some people did voice their opinion in these circumstances appeared puzzling, with Xi deeming it "interesting for me to see those people on Facebook that are not anonymous." Brenda, while ignoring the influence of regulatory policies and social norms, mentioned with a certain indifference the opportunities to engage in debate and struggles to justify non-active behavior online, "Everyone is just out there to just have a little bit of news. ... I'm someone who doesn't really comment a lot. I'd just read and see what's going on; then I'll share it with my friends. Yeah, but we won't really say much about it. Because we're not really into politics and stuff".

Despite barely engaging in the social media space, participants were tuned to the possibilities of constructing a public consensus online and were receptive to collective processes of information validation. TP introduced the notion of a DTF Index, discussed on Hardware Zone. Din Tai Fung is a popular Cantonese restaurant that is known to gather long queues at lunch or dinner time. A DTF queue is an indicator; it signals with certainty the presence of something happening for real (lunch or dinner time). The concept transposed to news circulating online helps assess the truthfulness of the statement made. Applied to social media conversations, the DTF index suggests that the aggregation of posts on a similar story marks a consensus and therefore acts as an indicator of truth. The DTF index institutes a large volume of comments or likes as a signal to authenticate the validity of a message circulating on social media. Indeed, Johnathan confirmed that repeating a story many times is a form of signaling, which not only helps assessing whether it is true but also influences perceptions of what is happening, "On online forums, I see a lot of people complaining. ... I noticed this trend of people complaining about their life, about their work, complaining about their salary And what I can

say is that, if they keep complaining in a way that foreigners actually impacted their lives, it actually tells me that foreigners are here to snatch their jobs. It's just that I haven't experienced it yet. But the fact that they are complaining it for years, then I believe that something is not right, I believe that's the way... why Singaporeans are angry."

Knowledge exchanged on public forums online seems to remove the sense of atomization and passivity as interviewees felt able to have a true picture of what others experience [50]. The knowledge built on social media allows users to maintain an illusion of universality and confirm that a specific belief may be shared and coordinated among many. Breena realized that the construction of such consensus online may happen at the expense of other valid narratives that individuals ignore as they are caught up in collective validation processes, "I say this is my country and my home because Singapore is really very secure. Sometimes we just don't really care. So we always talk trash, but we don't really see what's going on. Yeah. So there is a lot of things that the government gives Singaporeans. Or Singaporeans give Singaporeans. But you forget about it online. We don't see it. Or we just ignore it."

\section{Discussion}

This study has proposed theoretical elements and analyzed empirically co-opted marginality in the Singaporean context. We argue that co-opted marginality could be interpreted as a means to camouflage morally and normatively illegitimate contestation and make it acceptable. Over the years, researchers of racism online have pointed to strategies used by actors to recruit adherents by increasingly using sophisticated and unassuming discourse [51]. Traditionally explicit and blatant use of racism has become more subtle with prejudices getting trivialized, denigrated, and even denied [52]. Younger generations notably are more restrained in the use of hateful language and resort to almost undetectable micro-aggressions [53]. Within the citizen immigrant frame, co-opted marginality may serve as a communicative strategy to making prejudice-loaded and racist claims more palatable by flipping the discourse (we are not oppressors / we are victimized, or we are not anti-foreigner/ we are suffering).

On the other hand, co-opted marginality claimants are themselves denied fair hearing of their grievances. The cultural elite and authorities in Singapore have leaned towards associating the discourse with xenophobia and prejudicial anti- foreigner discourse, insinuating bigotry and reprehensible behavior. While the notion of marginality attracts sympathetic considerations, co- opted marginality, reactions to the feeling of relatively higher status individuals (white, citizens) of being pushed aside are viewed as 
dubious, suspicious, and non-receivable.

Despite a growing awareness of co-opted marginality online, the phenomenon has scarcely been examined. Most theories on nationalistic and nativist tendencies refer to the idea of threat coming from other groups. Co-opted marginality may point to a more nuanced collective identity construction process that is not based on well-established and stereotyped ideas about who and what foreigners entail but on shared perceptions of common personal experiences. Such experiences can be easily laid bare on a participative and reciprocal platform such as social media. Such a perspective suggests that social media, beyond encouraging self-censorship and spirals of silence, may shape signaling mechanisms and enable users to communicate more easily, resolve ambiguity, dissonance and coordinate private with public selves [54].

From a theoretical perspective, co-opted marginality focuses attention on the relativity of the notion of self-categorization, and calls for interrogating how collective identities based on group socio-psychological dependance emerge on social media. According to social identity theory, individuals form their identity by classifying or naming themselves in relation to other groups or social categories [54]. The co-opting and appropriation of marginality by social categories that normally do not evolve on the margins are perplexing as at first this seems to lack legitimacy and second, this does not fit within the established premises of social identity theory. Reasons why high-status groups support the co-opted marginality discourse and challenge their group's consensus of their group's dominance need to be further explored. We point to Foucauldian (1997) perspectives on discourse and power, which suggest that the media are not a transparent window into reality. They are infused with political discourses that define meanings, which, in turn, define ways of thinking and acting [55]. According to Foucault, individuals are constructed and normalized by the regimes of power under which they live: the interweaving of discourse and power produces a regime of relative truths that gets disseminated by the people in charge. The co-opting of marginalized identities makes the notion of status a site of contestation and confusion, and may be part of an emancipatory process that uses the participatory mechanism of social media to challenge rules and norms established by the regime of power.

\section{References}

[1] M. Davis, "Networked hatred: New technology and the rise of the right", Griffith Review, 2019.
[2] B. Jaipragas, "Abuse of Pinoys shows anti-foreign anger in Singapore", https://news.abs- cbn.com/focus/04/25/14/abusepinoys-show-anti- foreign-anger-singapore, April 25, 2014.

[3] L, Y. C. Lim, Singapore's Economic Development: Retrospection and Reflections, World Scientific Publishing, 2015.

[4] S.Vasoo and J. Lee, "Singapore: social development, housing and the Central Provident Fund," International Journal of Social

Welfare, 10(4), 2001, pp. 276-283.

[5] J. Tai, "Civil society groups 'alarmed' by surge of racism and xenophobia", The Straits Times.

https://www.straitstimes.com/singapore/civil- societygroups-alarmed-by-surge-of-racism-and- xenophobia, Singapore, May 28, 2014.

[6] M. Mathews and Z. Jiayi, "Sentiments on immigrant integration \& the role of immigrant associations", IPS Exchange Series published by the Institute of Policy Studies (IPS), 2016.

[7] The World Bank, https://data.worldbank.org/indicator/, 2020.

[8] T. Tan and C. Wong, "Fewer babies born, more deaths last year, as population ageing trend continues", The Straits Times, https://www.straitstimes.com/singapore/number-ofbirths-in-singapore-fell-to-eight-year-low-in-2017, Singapore, July 13, 2018.

[9] AsiaOne, "S'poreans have to understand need for immigrants: LKY", AsiaOne, https://www.asiaone.com/News/Latest+News/Singa pore/Story/A1Story20120204-325821.html, Singapore, February 4, 2012.

[10] J. M. Montsion, "When talent meets mobility: un/desirability in Singapore's new citizenship project", Citizenship Studies, 16(3-4), 2012, pp 469- 482.

[11] The Editors, "Singapore - Miracle at the Centre of the World", The Atlantic, https://www.theatlantic.com/business/archive/2012/ 05/singapore-miracle-at-the-center-of-the- world/257082/, 2012.

[12] SG Opposition Facebook Group, https://www.facebook.com/groups/sgopposition/per malink/6230614716438, September, 2020.

[13] Duruz and G.V Khoo, "Eating together: Food, space, and identity in Malaysia and Singapore", Journal of East Asian Studies, 15(3), Rowman \& Littlefield, 2014, pp. 479-481.

[14] Thompson, E. C. (2014). "Immigration, society and modalities of citizenship in Singapore", Citizenship Studies, 18(3-4), pp. 315-331.

[15] J.M Montsion and S. K. Tan. "Smell this: Singapore's curry day and visceral citizenship", Singapore Journal of Tropical Geography 37(2), 2016, pp. 209-223.

[16] Singapore Ministry of Manpower, https://stats.mom.gov.sg/Pages/Employment- SummaryTable.aspx, Singapore, 2020.

[17] M. Rajah, "From Third World to First'*: A Case Study of Labor Laws in a Changing Singapore", Labor Law Journal, 70(1), 2019, pp. 42-63.

[18] C. Tham Yuen, "Singaporeans' concerns over job competition from foreigners will be addressed", The Straits Times, Singapore, August 25, 2020.

[19] F.W Gatzweiler and H. Baumüller, "Marginality- A framework for analyzing causal complexities of poverty", Marginality, Springer, Dordrecht, 2014, pp. 27-40.

[20] H. D. Lasswell, "The structure and function of 
communication in society", The Communication of Ideas, 37(1), 1948, pp. 136-139.

[21] J.A. Del Pilar and J.O. Udasco, "Marginality theory: The lack of construct validity", Hispanic Journal of Behavioral Sciences, 26(1), 2004, pp. 3-15.

[22] B.T. Cullen and M. Pretes, "The meaning of marginality: interpretations and perceptions in social science", The Social Science Journal, 37(2), 2000, pp. 215-229.

[23] R. E. Park, "Human migration and the marginal man", American Journal of Sociology, 33(6), 1928, pp. 881-893.

[24] P.T. Mukherji, "Marginality, Marginalisation and the Idea of Justice", Marginalities in India, Springer, Singapore, 2018, pp. 13-23.

[25] L. Boltanski, and L. Thévenot, On Justification Economies of worth, 2006.

[26] E. Goffman, Interaction ritual: Essays on face-to-face interaction, 1967.

[27] A. Strauss, "A social world perspective", Studies in Symbolic Interaction, 1(1), 1978, pp. 119-128.

[28] A.E. Clarke, "Situational analyses: Grounded theory mapping after the postmodern turn", Symbolic interaction, 26(4), 2003, pp. 553-576.

[29] W.R. Neuman, The digital difference: Media technology and the theory of communication effects, Harvard University Press, 2016

[30] M.E. McCombs, D. L. Shaw, and D. H. Weaver, "New directions in agenda-setting theory and research", Mass Communication and Society, 17(6), 2014, pp. 781-8

[31] "Chan Chun Sing, Pritam Singh spar in Parliament over Singapore's foreign worker policy", You Tube, https://www.youtube.com/watch?v=DSCCnr6yPCU , January, 2020.

[32] C. Yong, "PM Lee on the dangerous antiimmigrant sentiment among some Singaporeans", The Straits Times, ttps://www.straitstimes.com/singapore/pm- lee-on-thedangerous-anti-immigrant-sentiment- among-somesingaporeans, Singapore, October 4, 2014.

[33] K. P Tan "Civic Society and the New Economy in Patriarchal Singapore: Emasculating the Political, Feminizing the Public", Crossroads: An Interdisciplinary Journal of Southeast Asian Studies, 15(2), 2001, pp. 95-122.

[34] C. George and G. Venkiteswaran, Media and Power in Southeast Asia, Cambridge University Press. 2019.

[35] X. Hao \& C. George, "Singapore journalism: Buying into a winning formula. In The global journalist in the $21 \mathrm{st}$ century", Routledge, 2012, pp. 101-113.

[36] S. A. Fritzen," Discipline and democratize: Patterns of bureaucratic accountability in Southeast Asia", Intl Journal of Public Administration, 30(12-14), 2007, pp. 1435-1457.

[37] M. Fuller and A. Goffey, "Digital Infrastructures and the Machinery of Topological Abstraction", Theory, Culture \& Society, 29(4-5), 2012, pp. 311- 333.

[38] K. Vaswani, "Concern over Singapore's anti-fake news law," BBC Online, https://www.bbc.co.uk/news/business47782470, April 4, 2019.

[39] H.Baharuddin, "Singapore GE2020: Lessons learnt from Singapore's first true Internet election", The Straits Times, https://www.straitstimes.com/politics/lessons-learnt- from- singapores-first-true-internet-election, Singapore, July 15 , 2020.

[40] D. Ganga \& S. Scott, S., "Cultural "insiders" and the issue of positionality in qualitative migration research: Moving "across" and moving "along" researcher-participant divides", Forum: Qualitative Social Research, 7(3), May, 2006.

[41] N.M. Noor and C. Leong, "Multiculturalism in Malaysia and Singapore: contesting models", International Journal of Intercultural Relations 37(6), 2013, pp. 714-726.

[42] C.B. Huat, "Multiculturalism in Singapore: An instrument of social control", Race \& Class 44(3), 2003, pp. 58-77.

[43] K. Xinghui and K.Lim, "Young Singaporeans are ready to talk about race. Are their parents?", The South China Morning Post, https://www.scmp.com/weekasia/politics/article/3094644/young-singaporeans- are-readytalk-about-race-are-their-parents, July 25, 2020.

[44] C. Tham Yues and R. Kurohi, "Singapore GE2020: WP candidate Raeesah Khan apologises for 'insensitive' remarks in posts", The Straits Times,

https://www.straitstimes.com/politics/wp-candidate- raeesahkhan-apologises-for-insensitive-remarks-in- posts, Singapore, July, 2020.

[45] D.C. Hallin, and P. Mancini, Comparing media systems: Three models of media and politics, Cambridge University Press, 2004.

[46] G. Rodan, Transparency and authoritarian rule in Southeast Asia: Singapore and Malaysia, Routledge, 2004.

[47] "Charlie Rose interviews Lee Kwan Yu", You Tube, https://www.youtube.com/watch?v=A8GwmsLXOx 8, 2009.

[48] E. Noelle-Neumann, "The spiral of silence: a theory of public opinion", Journal of Communication, 24(2), 1974, pp. 43-51

[49] A. Ramzy, "A Blogger Gets Jail Term in Singapore for Posts Said to Incite Ethnic Hatred", The New York Times, https://www.nytimes.com/2016/03/24/world/asia/bl oggergets-jail-term-in-singapore-for-posts-said-to- incite-ethnichatred.html, March 23, 2016.

[50] E. Katz, E, "Publicity and pluralistic ignorance: Notes on 'the spiral of silence", Public Opinion and Social Change, Springer, 1998, pp. 28-38

[51] L. G. McNamee, B.L. Peterson, and J. Peña, J. "A Call to Educate, Participate, Invoke and Indict: Understanding the Communication of Online Hate Groups", Communication Monographs, 77(2), 2010, pp. 257-280.

[52] C. Cresswell, K.A. Whitehead, and K. Durrheim, "The anatomy of 'race trouble' in online interactions", Ethnic and racial studies, 37(14), 2014.

[53] K. Durrheim, R.Greener, and K.A. Whitehead, "Race trouble: Attending to race and racism in online interaction", British Journal of Social Psychology, 54(1), 2015, pp. 84-99.

[54] M. B. Brewer, "The psychology of prejudice: Ingroup love and outgroup hate?", Journal of Social Issues, 55(3), 1999, pp. 429-444.

[55] M. Arribas-Ayllon and V. Walkerdine. "Foucauldian discourse analysis", The Sage Handbook of Qualitative Research in Psychology, 2008, pp. 91-108. 